Original Research

\title{
Kajian terhadap Kecenderungan Aspek Visual dalam Perancangan Produk Mode Berbasis Tenun Gedhog Khas Tuban
}

\author{
Hany Mustikasari ${ }^{1 *}$, Achmad Haldani Destiarmand ${ }^{1}$, Agus Sachari ${ }^{1}$ \\ ${ }^{1}$ Fakultas Seni Rupa dan Desain, Institut Teknologi Bandung, Jl Ganesha 10, Bandung-Indonesia 40132 \\ *corresponding author: lapetiteimmaculata@gmail.com
}

\begin{abstract}
Indonesia has a lot of cultural diversity which able to support the sustainability of the Creative Industries. Among them is gedhog woven, a traditional weaving cloth. Compared to other types of weaving such as ikat or songket, gedhog woven still lack in popularity in the consumer market. However, gedhog woven has the opportunity of further development into a weaving-based product in the fashion industry to aim high recognization in society. Consumer interests and perceptions of weaving-based products are analyzed through qualitative method in order to understand the consumer market. Experiment also conducted to obtain the final form of fashion products made from gedhog woven material. Product diversification refers to visual aspects in design such as shape, color, size, and proportion. Analysis of tendencies towards fashion product from woven materials obtained through this research. This can be utilized both for the foundation of further research as well as improving the quality and value of selling products in the consumer market.
\end{abstract}

Keywords: visual aspect, fashion, gedhog woven

\begin{abstract}
Abstrak- Indonesia memiliki banyak kekayaan budaya yang dapat mendukung keberlangsungan dari Industri Kreatif. Salah satunya adalah wastra nusantara berupa tenun gedhog. Dibandingkan dengan jenis tenun yang lain seperti ikat atau songket, tenun gedhog masih kurang popularitasnya di dalam pasar konsumen. Meski demikian, tenun gedhog tetap memiliki peluang pengembangan lebih lanjut menjadi sebuah produk dalam industri mode supaya makin dikenal oleh masyarakat. Minat dan persepsi konsumen terhadap produk berbasis tenun dianalisis melalui metodologi kualitatif dalam rangka memahami keinginan pasar. Selain itu, dilakukan pula eksperimen untuk memperoleh bentuk akhir produk mode yang terbuat dari material tenun gedhog. Diversifikasi produk mengacu kepada aspek visual dalam desain seperti bentuk, warna, ukuran, dan proporsi. Melalui penelitian ini diperoleh analisis dari kecenderungan masyarakat terhadap pemilihan produk mode yang terbuat dari material tenun. Hal ini dapat dimanfaatkan baik bagi landasan penelitian selanjutnya maupun bagi peningkatan kualitas dan nilai jual produk dalam pasar konsumen.
\end{abstract}

Kata kunci: aspek visual, mode, tenun gedhog

\section{PENDAHULUAN}

Pasar mode dalam industri kreatif di Indonesia merupakan salah satu subsektor yang mendatangkan kontribusi cukup tinggi. Konsumen terbesar adalah segmentasi perempuan dengan kisaran usia 15-29 tahun dari kelas sosial ekonomi menengah. Jika kita mengamati lebih dekat, industri mode masih didominasi oleh produk-produk bermerek dari luar negeri, yang ditujukan terutama bagi konsumen dari kelas sosial ekonomi menengah ke atas. Keterbatasan kuantitas produk lokal turut membentuk pola pikir masyarakat yang beranggapan bahwa produk luar memiliki kualitas yang lebih tinggi. Salah satu produk lokal yang memiliki potensi untuk dikembangkan dalam subsektor mode adalah produk berbasis kain tenun. Di dalam industri mode, tenun merupakan hasil dari industri kerajinan tekstil yang merupakan instrumen pendukung berlangsungnya proses kreasi.

Tenun merupakan wastra nusantara yang sarat dengan makna dan filosofi karena senantiasa menyertai tahapan dalam kehidupan manusia, mulai dari kelahiran, masa akil-balig, pernikahan, kehamilan, hingga kematian. Keberadaan tenun tersebar pada banyak wilayah di Indonesia dan lebih menyeluruh jika dibandingkan dengan batik. Akan tetapi kualitas dari perajin dan hasil tenunan masih membutuhkan peningkatan, baik dari segi taraf hidup maupun pengembangan tenun. Salah satu lembaga non-profit yang memiliki misi sosial untuk meningkatkan kondisi tenun di Indonesia adalah Cita Tenun Indonesia (CTI). Berdasarkan program yang dilakukan oleh CTI sejak 2008 , terdapat perubahan positif pada beberapa perajin dan tenunan yang dihasilkan di daerah tertentu. Tenun pun mulai dikenal oleh masyarakat. Namun lembaga ini masih belum dapat menjangkau semua perajin yang ada. Salah satu 
Hany, M., et al., Kajian terhadap Kecenderungan Aspek Visual dalam Perancangan Produk Mode Berbasis Tenun Gedhog Khas Tuban, KELUWIH: Jurnal Sains dan Teknologi, Vol.1(2), 110-118, Agustus 2020

daerah yang masih belum dijangkau oleh CTI adalah Tuban, Jawa Timur, yang menghasilkan tenun gedhog.

Kain tenun gedhog yang berasal dari daerah Tuban, Jawa Timur, telah menjadi bagian kehidupan bermasyarakat sejak abad ke-14. Kain tenun gedhog digunakan sebagai sandang atau pakaian, baik untuk kebutuhan sehari-hari maupun untuk keperluan ritual. Pada masa tersebut, penggunaan kain tenun gedhog Tuban diatur berdasarkan pembagian kasta dalam masyarakat. Terdapat perbedaan dalam jenis kain serta motif yang dapat digunakan oleh masyarakat jelata dan masyarakat berkasta tinggi. Filosofi yang terdapat pada kain tenun gedhog Tuban beraneka ragam, mulai dari pelindung, penolak bala, hingga melancarkan proses bertani dan berkebun.

Dibandingkan dengan jenis tenun lain seperti ikat atau songket, tenun gedhog masih kurang dikenal oleh masyarakat. Perajin hanya mengandalkan wisatawan yang datang ke Tuban dan melakukan transaksi secara langsung. Bentuk akhir dari tenun gedhog yang dihasilkan hanya berupa lembaran kain. Sangat jarang dijumpai adanya pengembangan bentuk produk yang dibuat dengan material tenun gedhog Tuban. Hal inilah yang mendorong dilakukannya penelitian terkait diversifikasi produk berbasis tenun gedhog Tuban. Dengan melakukan analisis terhadap minat dan persepsi konsumen di kelas menengah, akan diperoleh identifikasi kebutuhan terhadap produk mode berbasis tenun sebagai landasan dalam menemukan bentuk yang mampu menjawab permintaan konsumen potensial. Temuan tersebut juga diharapkan dapat membuka peluang bagi tenun gedhog dan produk dengan material tenun gedhog di pasar konsumen.

Dalam kaitannya dengan tenun gedhog Tuban, terdapat penelitian yang telah dilakukan sebelumnya oleh Fajar Ciptandi. Penelitian tersebut memiliki titik berat kepada transformasi tenun gedhog sebagai bagian dari tekstil tradisional yang perlu dilestarikan (Ciptandi, 2018). Bentuk pelestarian merujuk kepada pengembangan produk berupa pengolahan tenun sebagai lembaran kain dan lebih lanjut hingga kain tersebut menghasilkan busana siap pakai dengan melibatkan peran desainer. Pengolahan dilakukan dengan menambahkan tekstur dan pembatikan yang melibatkan komunitas perajin serta pembatik gedhog Tuban. Sementara penelitian ini sendiri merupakan pengembangan lebih lanjut dengan berfokus pada penemuan minat dan persepsi konsumen dari kelas menengah terhadap produk dengan material kain tenun. Eksperimen terhadap aspek visual dilakukan untuk menemukan bentuk, tata letak, dan proporsi material tenun gedhog untuk menghasilkan produk baru yang bukan berupa lembaran kain dalam upaya diversifikasi produk.

Penelitian ini sejalan dengan kajian mengenai transformasi tradisi menggunakan metode ATUMICS. Metode ATUMICS merupakan elemen mikro yang terdiri dari artefak, teknik, fungsi, material, ikon, konsep, dan bentuk. Transformasi tradisi perlu dilakukan supaya kearifan lokal dapat terus hidup dalam masyarakat, bukan melalui preservasi namun melalui cara menyelaraskan diri dengan kondisi dan perkembangan yang sedang terjadi dalam masyarakat modern (Nugraha, 2012). Sedangkan kajian mengenai kelas sosial dalam masyarakat banyak dibahas dalam teori-teori mengenai adopsi mode dan pengembangannya, seperti mode sebagai pembawa pesan komunikasi, diferensiasi sosial, dan identitas budaya.

Berdasarkan uraian permasalahan dan kajian teori tersebut, diasumsikan bahwa segmentasi kain tenun di Indonesia masih sangat luas, tidak terbatas hanya pada segmentasi kelas atas dengan kisaran usia 40 tahun ke atas saja. Namun luasan segmentasi tersebut juga harus diimbangi dengan penyesuaian kondisi produk terhadap permintaan konsumen. Proporsi kain tenun pada bentuk dan ukuran produk akan berdampak pada besaran harga produk akhir yang menjadi salah satu faktor pertimbangan dalam pembelian.

\section{METODE}

Metode yang digunakan dalam penelitian adalah kombinasi antara kualitatif dan eksperimen. Metode kualitatif digunakan untuk menganalisis minat dan persepsi konsumen terhadap produk dengan material kain tenun. Sedangkan metode eksperimen diterapkan 
Hany, M., et al., Kajian terhadap Kecenderungan Aspek Visual dalam Perancangan Produk Mode Berbasis Tenun Gedhog Khas Tuban, KELUWIH: Jurnal Sains dan Teknologi, Vol.1(2), 110-118, Agustus 2020

https://doi.org/10.24123/saintek.v1i2.2922

dalam proses merancang produk dengan material tenun gedhog Tuban yang sesuai dengan keinginan konsumen. Eksperimen diterapkan melalui teknik manipulasi tekstil untuk menghasilkan motif dan tekstur yang bersifat tactile pada kain tenun gedhog. Teknik tersebut dilakukan dengan tujuan meningkatkan estetika dan nilai produk akhir dari tenun gedhog.

Pengumpulan data dilakukan melalui berbagai teknik seperti studi lapangan, wawancara, dan kuesioner. Observasi atau studi lapangan dilakukan terhadap perajin dan masyarakat yang tinggal di Desa Kedung Rejo, Kecamatan Kerek, Kabupaten Tuban, Provinsi Jawa Timur. Observasi ini bertujuan untuk memperoleh informasi dan gambaran mengenai kondisi perajin, kegiatan menenun yang meliputi pemintalan, pewarnaan, teknik dan proses pembuatan, serta bagaimana peluang tenun gedhog yang mungkin muncul dari proses tersebut. Selama proses observasi, dilakukan pengambilan gambar berupa foto dan video untuk merekam aktivitas yang dilakukan oleh perajin.

Wawancara dilakukan kepada kolektor sekaligus penggiat tenun gedhog dan pakar di bidang tenun serta mode. Tujuannya adalah untuk menggali informasi serta pemahaman yang lebih mendalam mengenai kondisi kain tenun secara umum dan potensi pengembangannya di Indonesia. Instrumen yang diperlukan saat melakukan wawancara adalah skema pelaksanaan yang mencakup waktu dan tempat pelaksanaan, serta daftar pertanyaan yang diajukan kepada narasumber. Wawancara dilakukan melalui dua cara, secara terstruktur dan tidak terstruktur. Wawancara terstruktur berupa pertanyaan yang dikirimkan secara daring karena lokasi narasumber berbeda kota. Sedangkan wawancara tidak terstruktur dilakukan secara langsung kepada perwakilan dari pihak CTI, sehingga tidak berpatokan pada daftar pertanyaan yang baku dan dapat menggali informasi lebih mendalam terkait penelitian. Wawancara tidak terstruktur juga dilakukan kepada kolektor sekaligus penggiat tenun gedhog pada saat observasi dilakukan di Kecamatan Kerek.

Teknik kuesioner dilakukan secara daring melalui platform Google Form untuk memudahkan perolehan data terkait minat dan persepsi terhadap produk dengan material kain tenun. Instrumen yang dibutuhkan adalah daftar pertanyaan yang terbagi menjadi tiga kategori. Kategori pertama berkaitan dengan data demografis, geografis, dan psikografis. Kategori kedua berkaitan dengan minat dan perilaku responden terhadap kain tradisional. Kategori ketiga menitikberatkan kepada kecenderungan minat responden terhadap aspekaspek desain dalam produk berbasis tenun.

HASIL

Pengamatan yang dilakukan di Desa Kedung Rejo menghasilkan beberapa temuan antara lain kondisi kehidupan dan perekonomian perajin; mindset perajin terhadap tenun dan bagaimana hubungannya dengan proses produksi, wawasan terhadap material, cara mengolah material; jenis serta ragam hias pada tenun gedhog. Sedangkan dari wawancara diperoleh data mengenai kondisi perajin dan kain tenun secara umum di Indonesia; realita yang terjadi di pasar konsumen; peluang pengolahan yang mungkin dilakukan dalam rangka menghasilkan lembaran kain maupun bentukan produk; dan peluang produk dengan material kain tenun di Indonesia.

Kehidupan dan perekonomian perajin tenun gedhog di Desa Kedung Rejo terbilang sederhana layaknya masyarakat pedesaan. Aktivitas sehari-hari didominasi oleh kegiatan di ladang seperti menyiapkan tanah sebelum memasuki masa tanam, menyebar benih, dan memanen hasil bumi. Setelah menyebar benih dan sebelum masa panen terdapat jeda waktu yang biasanya digunakan oleh perajin untuk melakukan kegiatan menenun. Jadi aktivitas menenun adalah pengisi waktu luang dan bukan merupakan mata pencarian utama. Karena itu hasil produksi kain tenun tidak konsisten. Wawasan perajin gedhog terhadap material, cara pengolahan, dan jenis ragam hias masih sebatas pengetahuan yang diwariskan secara turuntemurun dari orang tua. Para perajin tenun gedhog adalah perempuan dengan kisaran usia diatas 40 tahun. 
Dari wawancara yang dilakukan terhadap narasumber, diperoleh informasi mengenai peluang tenun dalam masyarakat Indonesia yang memiliki beragam segmentasi. Tenun berpotensi untuk dijadikan produk kekinian dengan memperhatikan tren yang berlaku dan selera konsumen. Tantangan yang dihadapi oleh desainer terletak pada cara pengolahan kain tenun menurut karakteristiknya dan menerjemahkannya menjadi produk yang sesuai dengan keinginan konsumen.

Berdasarkan kuesioner uji minat, diperoleh data dari 101 responden dengan variasi kisaran usia kurang dari $20-64$ tahun, pendidikan didominasi oleh lulusan perguruan tinggi strata S-1, pendapatan per bulan rata-rata sebesar 2.500.000 - 5.000.000 Rupiah dengan anggaran belanja produk mode kurang dari 1.000.000 Rupiah setiap bulannya. Dari 101 responden, 63 orang di antaranya menyatakan ketertarikan terhadap produk mode yang terbuat dari material tenun. Responden bersedia membelanjakan sebesar 500.000 1.000.000 Rupiah untuk satu produk mode berbasis kain tenun dengan pertimbangan utama aspek motif, warna, kualitas material, dan harga produk. Dari keempat aspek tersebut, motif menjadi bahan pertimbangan utama dalam membeli produk dengan material dari kain tenun. Jenis motif kain tenun yang paling banyak diminati oleh responden adalah motif garis.

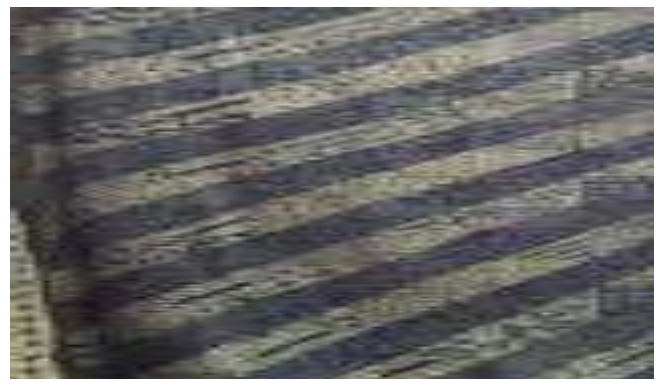

Gambar 1. Contoh motif garis pada tenun gedhog Tuban.

Sebanyak 62 orang atau sebesar $61.39 \%$ dari total responden cenderung menyukai produk dengan kain tenun sebagai aksentuasi. Dominasi pemilihan proporsi kain tenun berupa aksentuasi terjadi pada masing-masing kelompok usia. Sementara untuk pemilihan ukuran produk tidak terpaku pada besar-kecilnya melainkan pada kualitas. Sebanyak 34 dari 101 responden lebih menitikberatkan fokus kepada kualitas tanpa memedulikan ukuran produk. Dari total 34 tersebut, sebanyak 18 orang berasal dari kelompok usia 20-34 tahun. Meskipun demikian, dari 101 total responden terdapat 33 orang yang menyukai produk mode berukuran sedang. Jumlah tersebut hanya terpaut satu dengan responden yang lebih mementingkan kualitas daripada ukuran.

\section{Tabel 1}

Kecenderungan pemilihan proporsi berupa aksentuasi kain tenun pada produk

\begin{tabular}{cccc}
\hline Usia Resp (tahun) & Total Resp (orang) & $\begin{array}{c}\text { Aksentuasi Tenun } \\
\text { (orang) }\end{array}$ & $\%$ \\
\hline$<20$ & 11 & 7 & 63.64 \\
$20-34$ & 54 & 36 & 66.67 \\
$35-49$ & 29 & 14 & 48.28 \\
$>49$ & 7 & 5 & 71.43 \\
\hline Jumlah & 101 & 62 & \\
\hline
\end{tabular}


Hany, M., et al., Kajian terhadap Kecenderungan Aspek Visual dalam Perancangan Produk Mode Berbasis Tenun Gedhog Khas Tuban, KELUWIH: Jurnal Sains dan Teknologi, Vol.1(2), 110-118, Agustus 2020

https://doi.org/10.24123/saintek.v1i2.2922

Pemilihan nuansa warna kain tenun yang diaplikasikan ke produk didominasi oleh warna alam. Sebanyak 39 dari 101 responden lebih memilih nuansa warna alam dibanding warna lembut (pastel tone), warna cerah (vibrant), dan warna monokromatik.

Tabel 2

Kecenderungan pemilihan nuansa warna alam pada kain tenun

\begin{tabular}{cccc}
\hline Usia Resp (tahun) & Total Resp (orang) & $\begin{array}{c}\text { Warna Alam } \\
\text { (orang) }\end{array}$ & $\%$ \\
\hline$<20$ & 11 & 5 & 45.45 \\
$20-34$ & 54 & 21 & 38.89 \\
$35-49$ & 29 & 11 & 37.93 \\
$>49$ & 7 & 2 & 28.57 \\
\hline Jumlah & 101 & 39 & \\
\hline
\end{tabular}

Tampilan kontemporer menimbulkan kesan gaya modern yang lebih praktis dan mengikuti perkembangan jaman. Sebanyak $88.12 \%$ atau 89 orang dari total responden memilih tampilan kontemporer dibandingkan tradisional. Dari jumlah tersebut, sebesar 50 responden dengan kisaran usia 20-34 tahun menunjukkan minatnya terhadap tampilan kontemporer. Sebesar $68.32 \%$ atau 69 total responden memilih gaya klasik yang sederhana dan minimalis dibandingkan gaya eklektik. Dari persentase tersebut, 43 dari total 54 responden berusia 20-34 tahun menunjukkan kecenderungan terhadap gaya klasik.

\section{BAHASAN}

Pasar konsumen kain tenun dan produk mode yang terbuat dari kain tenun di Indonesia secara umum saat ini adalah kelompok usia lebih dari 40 tahun dengan kelas sosial ekonomi atas. Produk tenun di pasar konsumen memiliki harga jual relatif tinggi sehingga tidak dapat dijangkau oleh kelas menengah. Hal ini bertolak belakang dengan kondisi pasar terbesar produk industri kreatif di Indonesia yang justru berasal dari kelas sosial ekonomi menengah dengan kisaran usia 15-29 tahun. Menurut pembagian segmentasi usia dan generasi, kelompok usia tersebut terbagi menjadi 2 yakni 15-19 tahun sebagai generasi $Z$ dan 20-29 tahun sebagai bagian dari generasi $Y$. Generasi $Y$ yang lahir pada era perkembangan internet kerap disebut sebagai generasi milenial atau generasi net karena sangat dekat dengan teknologi daring. Generasi $Y$ telah terbiasa memanfaatkan media daring, baik dalam memperoleh informasi maupun dalam menciptakan sebuah bentuk eksistensi individu.

Berdasarkan kuesioner yang dilakukan terhadap responden dari berbagai kelompok usia pada umumnya dan terhadap kelompok usia 20-34 tahun sebagai generasi $Y$ pada khususnya, diperoleh data serta analisis terkait minat dan persepsi mereka terhadap produk mode yang terbuat dari kain tenun. Peminatan terhadap kain tenun dan produk mode dengan material dari kain tenun di Indonesia tidak terbatas pada satu kelompok usia dan kelas sosial ekonomi tertentu saja. Hal tersebut tampak dari antusiasme responden dari berbagai latar belakang kelas sosial ekonomi terhadap kain tenun dan produk mode dari kain tenun. Luasnya segmentasi di Indonesia yang meliputi berbagai kriteria demografis, geografis, psikografis, dan perilaku melahirkan karakteristik unik yang membedakan antara satu kelompok dengan yang lain. Oleh karena itu, kebutuhan serta keinginan terhadap sebuah produk pada kategori yang sama di tiap kelompok masyarakat mungkin akan berbeda wujud dan tampilannya.

Masyarakat Indonesia mengondisikan mode dan produk-produknya sebagai penanda akan adanya diferensiasi sosial dalam masyarakat. Diferensiasi tersebut dapat berupa kecenderungan terhadap selera dan identitas sosial. Peminatan yang timbul terhadap kain 
Hany, M., et al., Kajian terhadap Kecenderungan Aspek Visual dalam Perancangan Produk Mode Berbasis Tenun Gedhog Khas Tuban, KELUWIH: Jurnal Sains dan Teknologi, Vol.1(2), 110-118, Agustus 2020

https://doi.org/10.24123/saintek.v1i2.2922

tenun dan produk dari kain tenun menyebabkan timbulnya segmentasi baru dalam masyarakat. Namun segmentasi tersebut tidak merujuk kepada satu kelompok usia dan kelas sosial ekonomi tertentu saja melainkan lebih kepada selera konsumen potensial. Termasuk di dalamnya terdapat pertimbangan terkait kebutuhan dan keinginan konsumen. Selera konsumen dapat timbul pada berbagai segmentasi usia dan kelas sosial. Hal ini tampak dalam uji minat yang dilakukan pada berbagai kelompok usia yang menunjukkan mayoritas responden dari tiap kelompok menyatakan ketertarikan terhadap tenun. Selain itu, analisis mengenai selera konsumen ditunjukkan secara konkret melalui kecenderungan terhadap berbagai aspek visual dan prinsip-prinsip dalam desain.

Selain kecenderungan terhadap selera dan identitas sosial, diferensiasi dalam masyarakat juga dapat menandakan identitas kebudayaan pelaku mode. Wastra tradisional membawa identitas budaya melalui penggunanya. Baik budaya nasional pada umumnya maupun budaya lokal pada khususnya. Indonesia memiliki kain tenun dari berbagai daerah sehingga tiap-tiap jenis akan membawa serta filosofi dan nilai kedaerahan yang dimiliki.

Meskipun segmentasi pasar di Indonesia sangat luas sehingga membuka peluang yang besar sebagai produk kriya, kain tenun dan produk mode berbasis kain tenun tetap memiliki keterbatasan. Proses produksi yang dilakukan secara manual menyebabkan durasi pembuatan tidak dapat diprediksi. Ditambah dengan kondisi sosial budaya masyarakat perajin yang masih menempatkan tenun sebagai aktivitas untuk mengisi waktu luang dan bukan mata pencarian utama. Selain itu terdapat inkonsistensi pada hasil tenun sebagai karya kerajinan. Inkonsistensi dapat terjadi pada beragam proses, mulai dari pemintalan kapas, pewarnaan benang, hingga penenunan menjadi helaian kain, yang menyebabkan hasil akhir antara kain tenun yang satu dengan lainnya tidak benar-benar serupa. Pemintalan kapas yang dilakukan secara manual menghasilkan benang dengan ketebalan yang beragam. Dalam satu gulungan benang terdapat benang yang tipis, namun ada pula yang cukup tebal. Ketika melalui proses penenunan, akan menghasilkan kain dengan tampilan benang tebal dan tipis sehingga memperkaya tekstur permukaan kain. Proses pewarnaan juga dapat menghasilkan kain tenun dengan warna berbeda meskipun melalui proses pencelupan yang sama.

Hal-hal tersebut memberikan pemahaman bahwa tenun sebaiknya diterima sebagai sebuah karya seni, bukan karya pabrikan. Inkonsistensi yang timbul selama proses pembuatan hingga hasil akhir justru akan menambah nilai kain tenun sebagai salah satu produk kriya. Upaya untuk mengembangkan lembaran kain tenun menjadi sebuah bentuk baru pun harus merujuk kepada karya kriya. Material yang dihasilkan melalui proses manual akan mengalami kesulitan terutama dari aspek sumber daya dan produksi apabila harus dilakukan secara pabrikan karena membutuhkan kuantitas relatif besar.

Rumitnya proses pembuatan kain tenun turut membentuk pandangan dalam masyarakat bahwa kain tenun memiliki nilai jual yang tinggi. Ditambah dengan beredarnya produk mode dari kain tenun di pasar konsumen yang mayoritas mengarah kepada kategori couture sehingga harga jualnya relatif tinggi dan hanya dapat dijangkau oleh kelas sosial ekonomi atas. Yang kurang diketahui oleh masyarakat adalah keberagaman jenis tenun yang ada di Indonesia, material, motif yang dimiliki, teknik, cara dan proses pembuatan. Pengetahuan masyarakat mengenai kain tenun terbatas hanya pada jenis-jenis tertentu yang memang sengaja dipopulerkan dalam pasar konsumen. Tidak banyak yang memahami bahwa tingkat kerumitan dalam pembuatan kain tenun dapat memiliki banyak variasi. Untuk memenuhi kebutuhan dan keinginan konsumen dengan kisaran usia 20-34 tahun dari kelas menengah, dipilih jenis kain tenun yang lebih sederhana proses pembuatannya. Salah satu jenis yang sesuai adalah kain tenun gedhog yang berasal dari daerah Tuban, Jawa Timur. Tenun gedhog khas Tuban memiliki ragam hias berupa motif geometris yang mayoritas berupa garis.

Diversifikasi konsentris pada produk berbasis kain tenun gedhog dari Tuban menghasilkan wujud yang berbeda dengan bentuk asli. Jika bentuk asli berupa lembaran kain tenun, maka setelah diversifikasi akan menghasilkan produk baru dari kain tenun tersebut. Diversifikasi dilakukan dengan menerapkan metode ATUMICS. Namun dari tujuh elemen mikro 
Hany, M., et al., Kajian terhadap Kecenderungan Aspek Visual dalam Perancangan Produk Mode Berbasis Tenun Gedhog Khas Tuban, KELUWIH: Jurnal Sains dan Teknologi, Vol.1(2), 110-118, Agustus 2020

https://doi.org/10.24123/saintek.v1i2.2922

yang terdapat pada metode tersebut, tidak semua elemen mengalami transformasi. Untuk menjaga keberadaan dan filosofinya, artefak kain tenun gedhog tidak diubah baik dari segi corak maupun proses pembuatannya. Akan tetapi bentuk akhirnya mengalami perubahan.

Perubahan bentuk akhir tersebut disesuaikan dengan kondisi segmentasi pasar konsumen yang dituju sekaligus merujuk juga kepada hasil uji minat terhadap produk mode berbasis kain tenun. Jika sebelumnya kain tenun gedhog yang ada di pasar konsumen berupa lembaran kain, maka pada penelitian ini lembaran kain tersebut diolah lebih lanjut hingga menghasilkan produk mode berupa sarana bawa atau tas. Penemuan bentuk baru produk mode berupa tas dengan material dari kain tenun gedhog Tuban didasari oleh beberapa pertimbangan. Karakteristik kain tenun gedhog Tuban cukup tebal dan berat sehingga kurang sesuai apabila dijadikan pakaian untuk daerah tropis seperti Indonesia. Selain itu harus memperhitungkan faktor kenyamanan dalam penggunaan produk dan harga jual yang sesuai dengan kemampuan ekonomi dari konsumen kelas menengah.

Analisis lain yang juga diperoleh dari hasil uji minat adalah pengaruh aspek visual terhadap pemilihan kain tenun dan produk mode yang dihasilkan. Pertimbangan yang paling diutamakan ketika memilih produk kain tenun adalah motif tenun yang diaplikasikan pada produk. Mayoritas responden memilih motif garis, baik berupa garis lurus ataupun garis yang bersilangan sehingga membentuk kotak. Motif garis sendiri merupakan bagian dari ornamen geometris yang terdiri atas garis lurus maupun lengkung, serta raut pada bidang geometri. Bentuknya dapat berupa abstrak, setengah abstrak, atau menyerupai objek yang terdapat di alam namun yang bentuk aslinya tidak lagi dapat dikenali. Apabila bentuk asalnya masih dapat dikenali, maka motif tersebut termasuk dalam ornamen organis (Sunaryo, 2009). Pemilihan motif garis ini dapat dikaitkan dengan kecenderungan terhadap pemilihan gaya klasik yang juga mendominasi. Gaya klasik menggunakan detil seminimal mungkin dengan garis sebagai pilihan motif. Hal ini dikarenakan gaya klasik menciptakan tampilan yang modern, rapi, elegan, dan bertahan lebih lama dibandingkan gaya lain yang usang dalam kurun waktu 1-2 musim keluaran produk mode.

Selain motif kain tenun, terdapat aspek visual lain yang turut menjadi pertimbangan ketika responden membeli produk mode dari kain tenun, yakni warna. Terdapat kecenderungan minat terhadap nuansa warna alam seperti warna kecoklatan, biru, hijau, dan warna lain yang terdapat di alam. Minat terhadap warna alam juga dapat dikaitkan dengan kecenderungan terhadap gaya klasik yang banyak menggunakan warna-warna netral seperti putih, putih tulang, nuansa coklat, dan warna-warna gelap yang menciptakan kesan elegan. Pengelompokan usia tampaknya tidak terlalu berpengaruh terhadap pemilihan warna karena mayoritas responden dari tiap kelompok usia cenderung menyukai nuansa warna alam, kecuali pada kelompok usia lebih dari 49 tahun yang banyak memilih warna cerah.

Kualitas dan harga produk turut menjadi bahan pertimbangan dalam pembelian produk. Mayoritas responden bersedia mengalokasikan dana sebesar $500.000-1.000 .000$ Rupiah untuk membeli satu buah produk mode yang terbuat dari material kain tenun, namun nominal harga tersebut harus dibarengi dengan kualitas produk yang baik. Berdasarkan ukuran produk yang ditawarkan, responden lebih menitikberatkan perhatian pada kualitas bukan pada dimensi ukuran. Hal ini menunjukkan bahwa ukuran produk mode dengan material kain tenun dapat bervariasi mulai dari kecil, sedang, hingga besar, namun harus tetap dibarengi dengan kualitas yang baik.

Menurut proporsi kain tenun pada produk, terdapat kecenderungan responden lebih menyukai kain tenun sebagai aksentuasi dibandingkan kain tenun yang diaplikasikan secara menyeluruh. Kondisi ini sangat mungkin berkaitan dengan tingginya harga jual yang ditimbulkan apabila proporsi kain tenun cukup besar pada satu buah produk. Selain itu, mayoritas responden lebih menyukai tampilan kontemporer dibandingkan tampilan tradisional. Pada berbagai tampilan kontemporer, artefak tradisional yang diaplikasikan merupakan titik perhatian sehingga proprosinya lebih kecil dibandingkan produk secara keseluruhan. Apabila artefak tradisional diaplikasikan secara menyeluruh, terdapat pengolahan 
Hany, M., et al., Kajian terhadap Kecenderungan Aspek Visual dalam Perancangan Produk Mode Berbasis Tenun Gedhog Khas Tuban, KELUWIH: Jurnal Sains dan Teknologi, Vol.1(2), 110-118, Agustus 2020

https://doi.org/10.24123/saintek.v1i2.2922

terhadap motif atau warna supaya tetap menampilkan kesan modern. Aksentuasi yang dilakukan dengan menggunakan material dari kain tenun tanpa mengubah motif asli dapat dilakukan melalui berbagai teknik manipulasi tekstil seperti quilting, pleating, tucks, smocking, dan embroidery. Teknik manipulasi juga dapat menambah nilai estetis pada produk akhir.

\section{SIMPULAN}

Berdasarkan kajian dan analisis terhadap data yang diperoleh dalam penelitian, dapat disimpulkan bahwa kain tenun bukan milik kelompok tertentu dalam masyarakat Indonesia. Meski demikian, saat ini kain tenun serta produk yang dihasilkan dari kain tenun masih identik dengan perempuan dari kelompok usia di atas 40 tahun dan kelas sosial ekonomi atas. Hal tersebut dapat diakibatkan oleh keterbatasan produk yang ada di pasar konsumen. Pada dasarnya, peminatan konsumen terhadap kain tenun tidak bergantung kepada satu kelompok usia ataupun kelas sosial ekonomi tertentu saja. Hal ini menyebabkan besarnya peluang kain tenun dan produk mode yang terbuat dari kain tenun dalam pasar konsumen di Indonesia mengingat jumlah masyarakatnya yang cukup besar. Namun pengembangan kain tenun baik dalam wujud lembaran kain maupun yang telah menjadi bentuk baru, sebaiknya disesuaikan dengan kondisi segmentasi dan target konsumen yang dituju. Karena setiap kelompok memiliki karakteristik segmentasi yang unik, sehingga akan menimbulkan peminatan, kebutuhan, dan permintaan yang berbeda.

Pengembangan kain tenun dapat dilakukan dengan banyak cara, salah satunya adalah diversifikasi produk melalui transformasi dengan metode ATUMICS. Dari tujuh elemen mikro pada metode ATUMICS, dapat dipilih satu atau lebih elemen yang akan ditansformasi. Sebelum proses transformasi, perlu dilakukan kajian mendalam terlebih dahulu supaya dapat diperoleh analisis yang tepat terkait elemen yang perlu mengalami perubahan atau pengembangan. Selain itu, transformasi juga harus mempertimbangkan tujuan akhir karena akan berpengaruh terhadap tahapan-tahapan yang akan dijalankan demi mencapai perubahan. Sebagai bagian dari karya seni dan desain, perwujudan kain tenun menjadi sebuah bentuk baru dalam kategori produk mode berkaitan erat dengan aspek-aspek visual. Tidak hanya dari siluet atau bentuk luar tetapi lebih mendetil juga meliputi gaya, jenis tampilan, corak dan pemilihan nuansa warna. Di samping itu juga melibatkan penerapan prinsip-prinsip desain terutama dari segi proporsi. Produk mode juga berkaitan erat dengan gaya hidup masyarakat sehingga dalam menerapkan aspek visual maupun prinsip desain sebaiknya mengacu kepada prediksi tren yang berlaku dalam masyarakat. Prediksi tren menyediakan informasi mengenai kecenderungan yang terjadi dalam masyarakat, sehingga akan membantu dalam pembuatan produk mode yang mampu menjawab keinginan pasar konsumen.

Penelitian ini masih dapat dikembangkan lebih jauh dan mendalam, terutama jika dikaitkan dengan dinamika yang terjadi pada masyarakat sebagai konsumen produk. Setiap segmentasi dapat menjadi subjek penelitian yang menarik untuk dikaji dan menghasilkan analisis baru bagi dunia desain, khususnya mode. Kain tenun sendiri sebagai objek penelitian masih membutuhkan pengembangan dalam banyak hal, seperti proses produksi, pengolahan material, pewarnaan, motif, dan pemasaran. Hasil penelitian ini diharapkan dapat membantu mengangkat wastra nusantara khususnya tenun gedhog dalam masyarakat Indonesia khususnya dan dunia pada umumnya.

\section{PUSTAKA ACUAN}

Ciptandi, F 2018, 'Transformasi desain struktur tenun gedog dan ragam hias batik tradisional khas Tuban melalui eksperimen karakteristik visual', Disertasi Doktoral Institut Teknologi Bandung.

Nugraha, A 2012, 'Transforming tradition: A method for maintaining tradition in a craft and design context', Unigrafia, Helsinki.

Sunaryo, A 2009, 'Ornamen nusantara: Kajian khusus tentang ornamen Indonesia', Dahara Prize, Semarang. 
Hany, M., et al., Kajian terhadap Kecenderungan Aspek Visual dalam Perancangan Produk Mode Berbasis Tenun Gedhog Khas Tuban, KELUWIH: Jurnal Sains dan Teknologi, Vol.1(2), 110-118, Agustus 2020

\section{BIBLIOGRAFI}

Achjadi, Jk \& Natanegara, EA 2010, 'Tenun gedhog: The handloomed fabrics of Tuban, East Jawa', Media Indonesia Publishing, Jakarta.

Emir, T \& Wattimena, S 2018, 'Tenun gedhog Tuban', PT. Gramedia Pustaka Utama, Jakarta. Gaimster, J 2011, 'Visual research methods in fashion', Bloomsbury, London.

Jones, SJ 2011, 'Fashion design', Laurence King Publishing Ltd, London.

Posner, H 2011, 'Marketing fashion', Laurence King Publishing Ltd, London. 